\title{
Wojciech Dyba
}

Uniwersytet im. Adama Mickiewicza w Poznaniu

Wydziat Geografii Społeczno-Ekonomicznej i Gospodarki Przestrzennej

Zakład Geografii Ekonomicznej

wojciech.dyba@amu.edu.pl

(1) https://orcid.org/0000-0003-1554-5938

\section{Czynniki oraz efekty lokalizacji zakładu Volkswagena $\mathrm{w}$ powiecie wrzesińskim ${ }^{1}$}

\begin{abstract}
Zarys treści: $\mathrm{W}$ artykule przedstawiona została analiza czynników i efektów lokalizacji zakładu produkcyjnego Volkswagen Crafter w Białężycach koło Wrześni. Uzyskane wyniki oparte są na wywiadach przeprowadzonych z przedstawicielami przedsiębiorstwa i władz samorządowych oraz z mieszkańcami. Badanie pozwoliło wykazać, że w zakresie czynników lokalizacji - obok kosztowych (związanych z terenem inwestycji i ulgami podatkowymi) - znaczenie miały też czynniki zaopatrzeniowe (m.in. oczekiwana wydajność pracy) oraz „miękkie” (m.in. dobry wizerunek regionu, współpraca z władzami lokalnymi). Wśród korzyści dla powiatu wrzesińskiego, jakie wynikają z inwestycji i działań podejmowanych przez władze zakładu, są przede wszystkim: utworzenie nowych miejsc pracy, sponsoring lokalnych imprez i wydarzeń, finansowanie akcji prośrodowiskowych, a także wzrost obrotów w lokalnym sektorze usługowym, napływ mieszkańców i lokalizowanie firm współpracujących z Volkswagenem.
\end{abstract}

Słowa kluczowe: czynniki lokalizacji, efekty mnożnikowe, społeczna odpowiedzialność biznesu, Volkswagen, powiat wrzesiński

\section{Wprowadzenie: cel i zakres artykułu}

Czynniki i efekty lokalizacji w Polsce dużych przedsiębiorstw, szczególnie zagranicznych, są po 1990 r. jednym z istotnych przedmiotów badań polskich geografów ekonomicznych i ekonomistów (Dziemianowicz 1997, Stryjakiewicz 1999, Cieślik 2007, Tobolska 2017, Śleszyński 2018). Zagadnienie jest o tyle interesujące, że na wybór miejsca działalności wpływ mogą mieć zarówno elementy mierzalne, związane m.in. $z$ terenem pod wybraną działalność, infrastrukturą czy

1 Część zaprezentowanych $\mathrm{w}$ artykule wyników badań została opublikowana również w języku angielskim w artykule: Dyba W. 2020. Local impacts of large greenfield investments: the example of the Volkswagen car production plant in Września, Poland. Studies of the Industrial Geography Commission of the Polish Geographical Society, 34(2): 35-49. 
siłą roboczą, jak i elementy „miękkie”, trudno mierzalne, w tym m.in. wizerunek regionu lub przychylność do inwestorów i jakość obsługi w lokalnym urzędzie. Z kolei efekty inwestycji podzielić można na bezpośrednie - takie jak nowe miejsca pracy i wpływy podatkowe - oraz pośrednie, zaznaczające się $\mathrm{w}$ otoczeniu społeczno-gospodaczym, takie jak tworzenie nowych przedsiębiorstw współpracujących i wzrost dochodów ludności. Stąd też przyciąganie inwestycji, szczególnie dużych, oraz kształtowanie klimatu inwestycyjnego stało się istotnym celem dla regionalnych i lokalnych władz samorządowych (Domański 2001, Jarczewski 2012, Godlewska-Majkowska 2013, Dziemianowicz i in. 2019).

Celem badań przedstawionych $\mathrm{w}$ artykule była identyfikacja i analiza czynników lokalizacji zakładu koncernu Volkswagen w Białężycach koło Wrześni oraz efektów, jakie ta inwestycja przyniosła dla powiatu wrzesińskiego.

Część teoretyczna artykułu składa się z: rozdziału poświęconego definicjom, przykładom oraz klasyfikacjom czynników lokalizacji (Godlewska 2001, Tobolska 2011) oraz rozdziałów opisujących dwie koncepcje służące analizie efektów lokalizacji inwestycji dla otoczenia - efektów mnożnikowych (Stryjakiewicz 2004, Wiedermann 2008, Domański, Gwosdz 2010) oraz społecznej odpowiedzialności biznesu (Adamczyk 2009, Kudłak 2018).

W części empirycznej artykułu w pierwszej kolejności omówione zostały czynniki lokalizacji zakładu Volkswagena w powiecie wrzesińskim wraz z ich przyporządkowaniem do czynników o charakterze ogólnym i szczegółowym oraz rynkowym, kosztowym, zaopatrzeniowym i „miękkim” (na podstawie podziału wykorzystanego przez Tobolską 2011). Następne dwie sekcje poświęcone są analizie efektów inwestycji dla powiatu wrzesińskiego: pierwsza w świetle opinii przedstawicieli zakładu Volkswagena oraz lokalnych władz samorządowych, druga - w świetle opinii mieszkańców. Całości dopełnia podsumowanie z dyskusją na temat ograniczeń interpretacji wyników badania.

Wybór studium przypadku będącego podstawą niniejszych rozważań nie był przypadkowy. Inwestycja zrealizowana we Wrzesińskiej Strefie Aktywizacji Gospodarczej, około $40 \mathrm{~km}$ na wschód od Poznania, jest bowiem uznawana za największą w zachodniej Polsce w XXI w. - jej wartość szacuje się na 800-1000 mln euro.

\section{Metody badań}

Badania, których wyniki przedstawione są $\mathrm{w}$ artykule, zostały przeprowadzone w czerwcu 2019 r. na obszarze powiatu wrzesińskiego z wykorzystaniem metody indywidualnych wywiadów pogłębionych z przedstawicielami Volkswagena Poznań oraz lokalnego samorządu (gminnego i powiatowego), a także wywiadu kwestionariuszowego na próbie 415 mieszkańców. W ten sposób zebrane i skonfrontowane zostały opinie na temat czynników i efektów lokalizacji różnych podmiotów związanych $z$ inwestycją: przygotowujących ją od strony administracyjnej, realizujących ją oraz mogących odczuwać jej skutki. Założenie było takie, że opinie (zwłaszcza o efektach dla rozwoju lokalnego) mogą się różnić, 
gdyż przedsiębiorstwa ukazują swoje działania przede wszystkim w pozytywnym świetle, z kolei władze i mieszkańcy mogą dostrzegać zarówno pozytywne, jak i negatywne strony lokalizacji i funkcjonowania dużego zakładu produkcyjnego.

Badanie składało się $z$ dwóch zasadniczych etapów. W pierwszym przeprowadzone zostały indywidualne wywiady pogłębione z przedstawicielami Volkswagena Poznań oraz lokalnych władz samorządowych. Wśród respondentów byli zatrudnieni w dziale komunikacji i compliance przedsiębiorstwa oraz komórce ds. zrównoważonego rozwoju i zaangażowania społecznego. Kolejne dwa wywiady przeprowadzono ze starostą wrzesińskim i burmistrzem Wrześni oraz pracownikami - odpowiednio - urzędów powiatowego i gminnego, którzy przygotowali i przeprowadzali proces inwestycyjny od strony administracyjnej. Spotkania odbyły się w Poznaniu i Wrześni w czerwcu 2019 r. i trwały od 1,5 do 2 godzin każde. Pozyskane informacje zostały następnie uzupełnione źródłami wtórnymi, pochodzącymi z zasobów internetowych. W ten sposób określono czynniki lokalizacji inwestycji w Białężycach oraz korzyści z niej wynikające dla najbliższego otoczenia.

W drugim etapie przeprowadzono wywiady kwestionariuszowe wśród mieszkańców powiatu wrzesińskiego. Przeprowadzono je metodą bezpośrednich wywiadów z wykorzystaniem kwestionariuszy papierowych przez studentów studiów magisterskich kierunku gospodarka przestrzenna na Uniwersytecie im. Adama Mickiewicza w Poznaniu. Materiał zebrano podczas ćwiczeń terenowych „inwestycje w zagospodarowaniu przestrzennym”, które odbyły się w czerwcu 2019 r. na obszarze trzech największych miast powiatu wrzesińskiego: Wrześni, Nekli i Miłosławia. Opinie mieszkańców były zbierane w charakterystycznych miejscach: na rynkach, przy urzędach gminy, w okolicy centrów handlowych lub sklepów. Próbę badawczą stanowili dorośli mieszkańcy powiatu wrzesińskiego, a dobór respondentów był kwotowy, dokonany według wieku (7 kategorii), płci (2) i miejsca zamieszkania (2: miasto Września oraz pozostała część powiatu wrzesińskiego). Ogółem przeprowadzono 415 wywiadów, w tym 247 wśród mieszkańców Wrześni oraz 168 wśród osób, które zamieszkiwały powiat wrzesiński z wyłączeniem Wrześni. Biorąc pod uwagę liczbę mieszkańców powiatu wrzesińskiego (77 300 mieszkańców według stanu na 31 grudnia 2018 r.), badanie było reprezentatywne $z$ poziomem ufności wyników 95\%, przy błędzie maksymalnym $5 \%$. W celu przeprowadzenia wywiadów $z$ odpowiednimi grupami docelowymi w czasie badań terenowych wykorzystano dodatkowo telefony komórkowe studentów oraz narzędzia dostępne przez internet: formularz i arkusz Google. Studenci, po przeprowadzeniu ankiety przez telefon komórkowy z dostępem do sieci, wybierali $z$ listy profil ankietowanego (np. mężczyzna w wieku 18-24 lat, zamieszkały we Wrześni). W ten sposób możliwe było odnalezienie do próby pozostałych respondentów o wybranych charakterystykach.

Kwestionariusz wywiadu był krótki i składał się z kilku pytań: zmaksymalizowano $\mathrm{w}$ ten sposób szansę na uzyskanie rzetelnych odpowiedzi (respondenci nie ulegali zniecierpliwieniu lub znużeniu pytaniami). W jednym $z$ nich osoby biorące udział w badaniu zostały poproszone o ocenę $\mathrm{w}$ skali od 1 do 7 wplywu inwestycji Volkswagena na rozwój powiatu wrzesińskiego. Odpowiedź 1 oznaczała 
bardzo negatywny wpływ, 2 - negatywny, 3 - raczej negatywny, 4 - ani pozytywny, ani negatywny, 5 - raczej pozytywny, 6 - pozytywny, 7 - zdecydowanie pozytywny. Następnie respondenci mieli podać - w pytaniu otwartym - uzasadnienie dla swojej oceny, tzn. uzasadnić, dlaczego pozytywnie, neutralnie lub negatywnie oceniają wpływ nowego zakładu na otoczenie.

\section{Czynniki lokalizacji - pojęcie, rodzaje i przykłady}

Lokalizacja działalności gospodarczej (od łac. locare) to usytuowanie obiektu (określonej wielkości i rodzaju) lub grupy obiektów na danym terenie. Podjęcie decyzji o miejscu usytuowania przedsiębiorstwa $\mathrm{w}$ przestrzeni jest zagadnieniem istotnym z punktu widzenia przedsiębiorstwa, gdyż wpływa na możliwość generowania zysków i rozwoju działalności. Jest też istotne z punktu widzenia władz i lokalnej społeczności, gdyż przynosi zazwyczaj dalekosiężne, długotrwałe i często nieodwracalne skutki dla zagospodarowania przestrzennego obszaru oraz lokalnej sytuacji gospodarczej - co określa się pojęciem trwałości następstw decyzji lokalizacyjnych (Budner 2004).

Według Webera, prekursora geografii przemysłu (1909, za: Budner 2004), czynnik lokalizacji to jedna $z$ wyraźnie zarysowujących się korzyści, która przejawia się w działalności gospodarczej wówczas, gdy działalność ta jest prowadzona w określonym punkcie lub obszarze. Zdaniem autora korzyści te osiąga się poprzez oszczędności w kosztach produkcji. Według Webera do podstawowych czynników lokalizacji należą: czynnik transportu, czynnik pracy i korzyści aglomeracji (wynikające ze skupiania infrastruktury oraz firm współpracujących na obszarze miasta).

Kortus (1986, za: Tobolska 2011) definiuje czynniki lokalizacji przemysłu jako warunki (np. koszty), wpływy, siły i inne motywy, które w sposób pozytywny lub negatywny oddziałują na funkcjonowanie przemysłu w danym miejscu. Tarski (1963, za: Stryjakiewicz 2009) przez czynniki lokalizacyjne rozumie wszystkie okoliczności wpływające bezpośrednio na najkorzystniejszy wybór miejsca zakładu lub ośrodka produkcyjnego. Czynniki te oddziałują na wybór wariantu lokalizacyjnego i to, że lokalizacja może okazać się w określonym miejscu bardziej lub mniej korzystna dla władz przedsiębiorstwa.

Według Godlewskiej (2001) czynniki lokalizacji to specyficzne cechy poszczególnych miejsc mające bezpośredni wpływ na kształtowanie się nakładów inwestycyjnych w trakcie budowy obiektu (obiektów) firmy, a także rentowności netto działalności gospodarczej realizowanej w tych miejscach. Autorka - wśród głównych klasycznych czynników lokalizacji - wymienia czynnik transportu, zasoby pracy i korzyści aglomeracji, a także bazę surowcową, rynek zbytu, bazę energetyczną oraz czynnik wody $i$ ochrony środowiska.

Z kolei Budner (2004) definiuje czynniki lokalizacji jako wymogi i walory lokalizacyjne, gdyż z jednej strony są to pewne wymagania (potrzeby) stawiane przez inwestora, które powinny spełniać określone miejsca dla zapewnienia odpowiednich korzyści. Z drugiej zaś są to walory użytkowe, czyli wszystkie wartości, które 
oferuje określone miejsce $\mathrm{w}$ celu najlepszego zaspokojenia potrzeb inwestora. Analiza lokalizacyjna obejmuje czynniki ogólne i szczegółowe związane z wymogami inwestora i walorami miejsca. Czynniki ogólne to takie, które są związane $\mathrm{z}$ rentą położenia $\mathrm{w}$ regionie i gminie, a szczegółowe to te, które dotyczą bezpośrednio nieruchomości (gruntowej lub budynkowej), na której umieszczona zostanie inwestycja.

Znaczenie czynników lokalizacji zmieniało się na przestrzeni ostatnich dekad, a do klasycznych i relatywnie prostych do określenia czynników coraz częściej dochodziły elementy behawioralne (personalne), odnoszące się do subiektywnego postrzegania walorów miejsc, oraz instytucjonalne, związane z przepisami prawnymi, specjalnymi instrumentami finansowymi, możliwości negocjowania z administracją (szerzej o tym w pracach: Budner 2004, Wieloński 2005, Stryjakiewicz 2007, 2009, Płaziak, Szymańska 2014, Godlewska-Majkowska 2015). Stąd też współczesne czynniki lokalizacji dzieli się często na „twarde” i „miękkie”. Czynniki „twarde” to te, które są łatwo mierzalne, m.in. podaż powierzchni produkcyjnych lub biurowych, wysokość podatków lub finansowe zachęty inwestycyjne, podaż wykwalifikowanej siły roboczej, infrastruktura komunikacyjna, rynek zbytu, bliskość dostawców i kooperantów, instytucje otoczenia biznesu, ośrodki kształcenia. Z kolei czynniki „miękkie” to m.in. gospodarczy wizerunek miejsca lokalizacji, przychylne nastawienie władz samorządowych do inwestora, mentalność i wydajność pracowników, klimat społeczny czy atrakcyjność lokalizacji dla pracowników i rodzin.

Tobolska (2011), w odniesieniu do inwestycji zagranicznych, dzieli czynniki lokalizacji na cztery grupy: a) rynkowe (związane z poszerzeniem rynków zbytu lub umocnieniem na nim swojej pozycji); b) kosztowe (wynikające $z$ korzystniejszych relacji kosztów w kraju docelowej inwestycji niż w kraju macierzystym, np. kosztów pracy, energii, obciążeń finansowych, usług finansowych); c) zaopatrzeniowe (polegające na zapewnieniu dostaw surowców, dostępu do technologii lub pracowników o odpowiednich kwalifikacjach) oraz d) strategiczne (związane z pozyskiwaniem strategicznych aktywów - know-how, technologii, kanałów dystrybucji - pozwalających utrzymać lub zwiększyć konkurencyjność na rynku regionalnym i globalnym). W analizie czynników lokalizacji trzech przedsiębiorstw: Exide Technologies SA w Poznaniu, Swedwood Poland Sp. z o.o. w Chlastawie i Volkswagen Motor Polska Sp. z o.o. w Polkowicach autorka przyporządkowuje zidentyfikowane czynniki lokalizacji do tych kategorii, dodatkowo wskazując czynniki mające wpływ na podjęcie decyzji lokalizacyjnych, które miały charakter miękki.

Analiza czynników lokalizacji przedsiębiorstw w Polsce, szczególnie zagranicznych, była również jednym $z$ elementów rozważanych $\mathrm{w}$ wielu innych pracach dotyczących bezpośrednich inwestycji zagranicznych (Stryjakiewicz 1999, Domański 2001, Wdowicka 2005, Stachowiak 2007), a także w pracach o roli władz samorządowych w przyciąganiu inwestorów (Jarczewski 2012, Godlewska-Majkowska 2013, Dziemianowicz i in. 2019). Analiza ta często poprzedza również rozważania nad efektami lokalizacji i funkcjonowania przedsiębiorstwa dla otoczenia. 


\section{Efekty mnożnikowe inwestycji}

Efekty mnożnikowe inwestycji to koncepcja, która głosi, że pozytywne rezultaty inwestycji w działalności gospodarczej pojawiają się po powstaniu przedsiębiorstwa lub później, w wyniku jego zwiększonej aktywności, gdy „pomnożone” zostają zyski i zatrudnienie $w$ innych, powiązanych przedsiębiorstwach na pewnym obszarze (Rachwał, Wiedermann 2008, Domański, Gwosdz 2010). Efekty mnożnikowe to suma wszystkich bezpośrednich i pośrednich korzyści powstających w wyniku działalności rozpatrywanego przedsiębiorstwa, zaznaczających się nie tylko w miejscu jego lokalizacji, ale także na innych obszarach i w powiązanych sektorach działalności (Stryjakiewicz 2004). Korzyści te - pozytywne rezultaty funkcjonowania dużych przedsiębiorstw w gospodarce regionalnej i lokalnej mogą być rozpatrywane dwojako (Stryjakiewicz 2004, Tobolska 2010). Z jednej strony w aspekcie efektów popytowych (zaopatrzeniowych) - wzrostu zapotrzebowania na działalność przedsiębiorstw będących dostarczycielami surowców, półproduktów i usług. W szczególności rozwijać się może działalność związana z: a) dostarczaniem surowców i półproduktów, b) podwykonawstwem lub outsourcingiem (przekazywaniem niektórych funkcji innym podmiotom gospodarczym), c) odbiorem gotowych produktów, d) rozwojem tzw. otoczenia biznesu (instytucji wspierających funkcjonowanie przedsiębiorstw). Możliwe jest zwiększenie zatrudnienia $\mathrm{w}$ podmiotach oferujących takie działalności, a kooperacja z przedsiębiorstwem, często innowacyjnym, wpływać może na poprawę poziomu produktów, technologii i organizacji produkcji w przedsiębiorstwach współpracujących, które zyski ze zwiększonej liczby zleceń mogą przeznaczyć na inwestycje (Domański 2001, Rachwał, Wiedermann 2008). Z drugiej strony powstają również efekty dochodowe jako skutek zwiększania się siły nabywczej ludności, której wydatkowane wynagrodzenie za pracę przyczynia się do rozwoju przedsiębiorstw ze sfery usług zaspokajających ich potrzeby. Podatki dochodowe i lokalne płacone przez podmioty gospodarcze i pracowników wpływają ponadto na wzrost dochodów państwa oraz samorządów terytorialnych (Wiedermann 2008, Domański, Gwosdz 2010).

Powstawanie efektów mnożnikowych rozpatrywać można w dwóch etapach (Domański 2002, Stryjakiewicz 2004, za: Lloyd, Dicken 1972, ze zm.). Początkowe efekty mnożnikowe lokalizacji dużego przedsiębiorstwa, w tym transnarodowego, osiągane są $\mathrm{w}$ wyniku kształtowania się nowego popytu lokalnego. Popyt ten jest kreowany poprzez: 1) przyciąganie działalności związanych, 2) nowe działalności inwestycyjne: budowlane i infrastrukturalne, 3) rozszerzenie sektora usług działających na rzecz nowego przedsiębiorstwa, 4) nowe możliwości wynalazczości i innowacji. Przyciąganie działalności towarzyszących obejmuje powiązania uprzednie i następcze $\mathrm{w}$ łańcuchu produkcji. Pierwsze $\mathrm{z}$ nich dotyczą budowy sieci powiązań z dostawcami surowców, materiałów i półproduktów. Drugie to sieci powiązań z odbiorcami produktów. Działalność firm świadczących usługi na rzecz przedsiębiorstwa, a także współpraca z podmiotami otoczenia biznesu lub placówkami badawczo-rozwojowymi prowadzą z czasem do dodatkowych inwestycji i wtórnych efektów mnożnikowych. Mogą one być rozumiane 
jako wyższe dochody lokalne, większe zróżnicowanie struktury gospodarczej, poprawa wizerunku regionu jako miejsca lokalizacji nowych inwestycji, przyciąganie nowych przedsiębiorstw czy w końcu osiągnięcie nowego poziomu rozwoju lokalnego i regionalnego (Domański i in. 2005, Zioło 2009). Władze lokalne wymieniają niekiedy jednak również negatywne dla lokalnego otoczenia efekty inwestycji zagranicznych, takie jak niekorzystny wpływ na środowisko ze względu na stosowane techniki produkcji, problemy i napięcia społeczne, m.in. w wyniku wzrostu bezrobocia oraz bankructwa lokalnych firm konkurujących z zagranicznym podmiotem (Dziemianowicz 1997).

Zdaniem Tobolskiej (2010) efekty lokalizacji bezpośrednich inwestycji zagranicznych w skali regionalnej i lokalnej można podzielić na 4 kategorie: a) skutków ekonomicznych (takich jak: wzrost dochodów jednostek samorządowych, wzrost dochodów mieszkańców, rozwój gospodarki regionu poprzez związki kooperacyjne, nowe inwestycje, wzrost innowacyjności, zmiany na rynku pracy); b) skutków społecznych(takich jak: nowe możliwości pracy i rozwoju - nowa struktura społeczna, zmiany w poziomie i warunkach życia, sponsoring wydarzeń, kształtowanie się postaw mieszkańców wobec inwestora); c) skutków w środowisku naturalnym (takich jak: wykorzystywanie zasobów lokalnych surowców mineralnych, emisja zanieczyszczeń i związków szkodliwych do otoczenia, wprowadzenie do środowiska odpadów poprodukcyjnych, działania na rzecz poprawy jakości środowiska; d) skutków przestrzennych (takich jak: zmiany w użytkowaniu gruntów, zmiany w zagospodarowaniu przestrzennym, nowe elementy infrastruktury, nowe formy koncentracji przestrzennej podmiotów gospodarczych, nowe powiązania przestrzenne, np. migracje dzienne pracowników).

Przedmiotem szczegółowych studiów przypadku - analiz wpływu dużych przedsiębiorstw na różne aspekty rozwoju lokalnego i regionalnego w Polsce były dotychczas m.in. Mazurskie Meble International (Dziemianowicz 1997), GlaxoSmithKline Pharmaceuticals w Poznaniu (Stryjakiewicz 2004), Sweedwood w Chlastawie - obecnie IKEA Industry Poland (Tobolska 2010), a także Exide Technologies i Volkswagen Motor Polska w Polkowicach (Tobolska 2011, 2017). Prace te wyjaśniają na konkretnych przykładach wybrane efekty mnożnikowe inwestycji; pokazują również elementy społeczne i przyrodnicze będące przedmiotem szczegółowych rozważań w koncepcji społecznej odpowiedzialności biznesu.

\section{Społeczna odpowiedzialność biznesu}

Społeczna odpowiedzialność biznesu (ang. CSR - Corporate Social Responsiblility) to koncepcja ukazująca znaczenie przedsiębiorstw dla otoczenia społecznego. Koncepcja powstała w opozycji do tradycyjnego ekonomicznego założenia przypisywanego Friedmanowi, głoszącego, że jedynym celem działalności przedsiębiorstw jest maksymalizacja zysku w imię zobowiązań wobec udziałowców. Zakłada, że władze przedsiębiorstwa mogą i powinny działać również $\mathrm{w}$ interesie społecznym, uwzględniając w swoich decyzjach społeczne i środowiskowe skutki podejmowanych działań. Respektowanie zasady ma swoje uzasadnienie etyczne 
i środowiskowe. $Z$ jednej strony to społeczeństwo nadaje przedsiębiorcy status prawny i przywileje oraz zezwala na wykorzystywanie zasobów środowiska naturalnego. $Z$ drugiej - zachodzi konieczność ochrony przyrody dla przyszłych pokoleń. Z punktu widzenia korporacji częstym celem stosowania CSR jest kreowanie pozytywnego wizerunku firmy, odróżnianie siebie i swoich produktów od innych firm, a w konsekwencji realizacja celów ekonomicznych w postaci zwiększania sprzedaży i kreowania zysków (Adamczyk 2009, Bernatt 2009, Caroll, Shabana 2010, Kudłak 2018).

Często przywoływana definicja CSR sformułowana została w Zielonej Księdze Komisji Europejskiej w sprawie koncepcji społecznej odpowiedzialności. Jest to „koncepcja, według której przedsiębiorstwa dobrowolnie uwzględniają aspekty społeczne i ekologiczne w swoich działaniach handlowych oraz w kontaktach ze swoimi interesariuszami (ang. stakeholders) (...). To inaczej ciągłe zobowiązanie biznesu do etycznego zachowania oraz przyczyniania się do rozwoju ekonomicznego, przy równoczesnej poprawie jakości życia siły roboczej i jej rodzin, jak również lokalnej społeczności i społeczeństwa jako ogółu" (Zielona Księga... 2001). Idea przewodnia CSR stanowi również element normy ISO 26000 uznanej w 2010 r. przez Międzynarodową Organizację Standaryzacyjną (International Standarization Organization, ISO). Społeczna odpowiedzialność biznesu jest tam zdefiniowana jako zobowiązanie organizacji do włączania aspektów społecznych i środowiskowych w proces podejmowania decyzji oraz wzięcie odpowiedzialności za wpływ podejmowanych decyzji i aktywności na społeczeństwo i środowisko.

Koncepcja ma cztery wymiary: ekonomiczny, prawny, etyczny i filantropijny. Wymiar ekonomiczny, uznawany za podstawowy, wynika z faktu, że tworzenie wartości ekonomicznej jest niezbędne zarówno z punktu widzenia firmy, jak i społeczeństwa. Wymiar prawny oznacza konieczność przestrzegania norm i regulacji prawnych. Jednocześnie przedsiębiorstwo powinno kierować się etyką biznesu oraz, o ile to możliwe, chęcią podejmowania działalności filantropijnej. Do wspólnych elementów rozumienia CSR należą: a) dobrowolny charakter działań podejmowanych przez przedsiębiorstwa, b) realizacja działań poprawiających dobrobyt społeczny oraz stan środowiska przyrodniczego, c) włączenie celów pozaekonomicznych do działalności podmiotów gospodarczych oraz d) rozszerzenie perspektywy działalności przedsiębiorstw poza interes właścicieli i udziałowców, a także uwzględnienie wpływu przedsiębiorstwa na inne grupy interesariuszy (Kudłak 2018).

Wśród szczegółowych obszarów, w jakich przedsiębiorstwa odpowiedzialne społecznie powinny podejmować działania, wymienia się: ład korporacyjny i zachowania wobec pracowników (interesariuszy wewnętrznych), uczciwość biznesową (wobec kontrahentów i klientów) oraz ochronę środowiska i zaangażowanie społeczne (wobec interesariuszy zewnętrznych, niezwiązanych biznesowo z działalnością przedsiębiorstwa). Ostatni z tych elementów jest szczególnie istotny z punktu widzenia wpływu podmiotów gospodarczych na otoczenie regionalne i lokalne. W ten sposób analiza społecznej odpowiedzialność biznesu powinna być traktowana jako istotny element geografii przedsiębiorstw (Kilar 2018). 


\section{Czynniki lokalizacji zakładu Volkswagena w powiecie wrzesińskim}

Nowy zakład Volkswagena powstał w Białężycach - na obszarze wiejskim w gminie Września, w województwie wielkopolskim, około $40 \mathrm{~km}$ na wschód od Poznania. Województwo wielkopolskie - obok województw śląskiego, mazowieckiego, dolnośląskiego i małopolskiego - od kilkunastu lat jest uznawane za region cechujący się dużą atrakcyjnością inwestycyjną. Wynika to w szczególności z wyróżniających je na tle innych regionów w kraju takich cech, jak: dostępność transportowa, zasoby i niskie koszty pracy, a także aktywność wobec inwestorów, bezpieczeństwo publiczne, infrastruktura gospodarcza i rynek zbytu (Atrakcyjność inwestycyjna województw... 2014). Województwo jest jednym z najlepiej rozwiniętych gospodarczo województw w Polsce i charakteryzuje się wysoką koncentracją kapitału zagranicznego zaangażowanego w Polsce oraz wysokimi nakładami inwestycyjnymi na 1 mieszkańca. Wśród głównych atutów województwa - na tle innych województw - wymienia się: a) równomierny rozwój gospodarczy przy znacznym stopniu uprzemysłowienia oraz wysokim poziomie technologicznym, b) wysoki potencjał kapitału ludzkiego, który jest kształtowany dzięki obecności w województwie najlepszych uczelni wyższych w Polsce, c) dobre połączenia komunikacyjne, d) historyczne uwarunkowania i dynamiczny rozwój Poznania - silnego ośrodka przemysłu, handlu, kultury oraz szkolnictwa wyższego i nauki. Region jest szczególnie dobrym miejscem dla inwestycji w przemyśle oraz działalności naukowej, profesjonalnej i technicznej (Atrakcyjność inwestycyjna regionów 2017).

Inwestycja w Białężycach została przeprowadzona na obszarze niezagospodarowanym, na „zielonym polu”, stąd należy ją traktować jako typową inwestycję typu greenfield.

Wolny, niezagospodarowany teren pod inwestycję był gotowy już w latach 2010-2013; w 2014 r. został nagrodzony w konkursie „Grunt na medal” organizowanym przez Polską Agencję Informacji i Inwestycji Zagranicznych S.A. ${ }^{2} 18$ kwietnia 2014 r. koncern Volkswagen został oficjalnie ogłoszony jako inwestor, który wybrał teren pod Wrześnią do zainwestowania. 13 listopada 2014 r. odbyła się uroczystość wmurowania kamienia węgielnego pod budowę nowej fabryki, a już 24 października 2016 r. nastąpiło oficjalne otwarcie fabryki. Inwestycja została zrealizowana na powierzchni 220 ha, co odpowiada powierzchni 300 boisk piłkarskich. Tak dużą budowę od rozpoczęcia do zjechania pierwszego auta z linii produkcyjnej udało się ukończyć w 24 miesiące, co wskazuje na niezwykle szybkie i sprawne jej przeprowadzenie. W nowej fabryce produkowany jest Volkswagen Crafter - model samochodu dostawczego w 69 wariantach, obejmujących m.in. różne typy nadwozia, silników czy wyposażenia (Kaczyńska 2014, Fijałkowski 2016).

$\mathrm{Na}$ podstawie informacji uzyskanych od przedstawicieli Volkswagena oraz urzędów miejskiego i powiatowego we Wrześni określono dziesięć najważniejszych czynników lokalizacji. Zostały one podzielone na ogólne - związane z rentą

Polska Agencja Informacji i Inwestycji Zagranicznych - to spółka akcyjna należąca do Skarbu Państwa, funkcjonująca pod tą nazwą do lutego 2017 r., kiedy to została przekształcona na funkcjonującą do dzisiaj Polską Agencję Inwestycji i Handlu. 
położenia w Wielkopolsce i powiecie wrzesińskim - oraz szczegółowe, dotyczące bezpośrednio nieruchomości, niezagospodarowanego terenu w Białężycach. Następnie zaklasyfikowano je również do czynników o charakterze rynkowym, kosztowym, zaopatrzeniowym i miękkim (tab. 1).

Tabela 1. Czynniki lokalizacji zakładu Volkswagena w Białężycach koło Wrześni

Czynnik

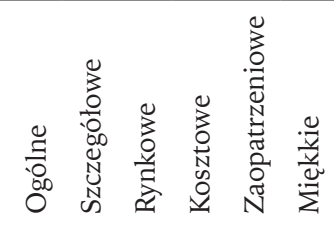

1 Położenie terenu pod inwestycję w zachodniej Polsce, bliskość granicy z Niemcami, a więc rynku niemieckiego i zachodnioeuropejskiego, utrzymanie pozycji lidera w produkcji samochodów w Polsce.

2 Bliskość siedziby Volkswagen Poznań Sp. z o.o. oraz istniejących w Poznaniu i aglomeracji poznańskiej zakładów Volkswagena, co stwarza możliwość połączenia centrali zarządzającej oddziałami, wymiany kadry, szybkich przejazdów między oddziałami.

3 Siła robocza: obecność wykwalifikowanych pracowników oraz potencjalnych pracowników produkcyjnych, niskie koszty pracy, dobra wydajność i jakość polskich pracowników.

4 Dobra infrastruktura transportowa: bliskość autostrady A2 oraz $x$ drogi krajowej nr 92 (Poznań-Warszawa), przebieg trasy kolejowej nr 3 (Poznań-Warszawa).

5 Położenie terenu pod inwestycję w województwie wielkopolskim regionie o dobrym wizerunku gospodarczym i wysokim poziomie rozwoju.

6 Dobre przygotowanie i przedstawienie walorów terenu w ramach tzw. marketingu terytorialnego przez władze samorządowe, inicjatywa i współpraca władz lokalnych przy przygotowaniu dokumentacji inwestycji.

7 Duży, płaski i wolny teren do zagospodarowania, dobry pod dużą inwestycję typu greenfield (wraz z rezerwą terenu pod ewentualną rozbudowę zakładu).

8 Położenie na terenie Wrzesińskiej Strefy Aktywizacji Gospodarczej, co wiąże się $z$ dokładną dokumentacją i rozpoznaniem terenu, a także pokryciem tego terenu miejscowym planem zagospodarowania przestrzennego.

9 Położenie na terenie podstrefy Wałbrzyskiej Strefy Ekonomicznej „Invest Park" (358,2 ha), co wiąże się ze zwolnieniem z podatku od nieruchomości na okres 5 lat i ulgą w podatku CIT.

10 Wynegocjowane $z$ urzędami i podmiotami gospodarczymi warunki szczegółowe, m.in. w zakresie rozbudowy infrastruktury i doprowadzenia mediów, a także możliwość lokalizacji w pobliżu przedsiębiorstw współpracujących.

Źródło: opracowanie własne na podstawie informacji uzyskanych od przedstawicieli przedsiębiorstwa Volkswagen Poznań oraz lokalnych władz samorządowych. 
Wywiady pozwoliły wykazać, że dla wyboru lokalizacji zakładu Volkswagena w Białężycach koło Wrześni największe znaczenie miały elementy kosztowe związane z siłą roboczą, kosztem zakupu gruntu i realizacji budowy, zwolnieniami podatkowymi, istniejącą infrastrukturą transportową. Istotna była również bliskość zakładu Volkswagen Poznań Sp. z.o.o. - samochody użytkowe, stanowiącego inny oddział niemieckiego koncernu Volkswagen AG. Zakład ten z placówkami produkcyjnymi w dzielnicach Antoninek i Wilda w Poznaniu oraz w strefie aktywizacji gospodarczej w podpoznańskim Swarzędzu funkcjonuje z powodzeniem już od kilkunastu lat (Dyba 2013), co stworzyło możliwość wspólnego zarządzenia oboma zakładami.

Dla lokalizacji zakładu koło Wrześni ważne były również elementy rynkowe, w tym pozycja lidera w produkcji samochodów użytkowych na rynku polskim połączona z bliskością Niemiec i innych krajów Europy Zachodniej tworzących potencjalne rynki zbytu produkowanych w zakładzie aut. Wreszcie nie bez znaczenia były czynniki miękkie, trudno mierzalne. Wśród nich wymienić można wizerunek gospodarczy regionu - województwa wielkopolskiego - oraz działania podejmowane przez lokalne władze samorządowe, w tym przede wszystkim wcześniejsze przygotowanie i wypromowanie terenu inwestycyjnego. To m.in. dzięki nim wolny teren w Białężycach koło Wrześni na ostatnim etapie rywalizacji okazał się korzystniejszy niż rozważany na tym etapie konkurencyjny obszar w Stargardzie w województwie zachodniopomorskim (por. Wojtyra, 2019).

\section{Efekty inwestycji dla otoczenia w świetle opinii przedstawicieli zakładu Volkswagena oraz lokalnych władz samorządowych}

W zakładzie w gminie Września w pierwszym roku działania pracowało 2760 osób. Po jego otwarciu Volkswagen Poznań stał się nie tylko największym producentem samochodów w Polsce (w 2018 r. taśmy produkcyjne opuściło 266819 samochodów takich modeli, jak Caddy, Crafter, T6, MAN TGE 9), lecz również największym pracodawcą w Wielkopolsce (wg danych na koniec 2019 r.), dającym zatrudnienie ponad 11 tys. osób ${ }^{3}$. Wpływ na lokalny i regionalny rynek pracy to z pewnością największa korzyść z otwarcia zakładu.

Przedstawiciele Volkswagena wymieniają jednak wiele innych korzyści z inwestycji dla otoczenia. Zgodnie z podstawowym zakresem koncepcji społecznej odpowiedzialności biznesu, podzielić je można na działania na rzecz społeczności lokalnej oraz działania na rzecz środowiska przyrodniczego (tab. 2).

Za swoją działalność zakład Volkswagen Poznań otrzymał w kwietniu 2019 r. „Biały Listek CSR”, wyróżnienie dla najbardziej odpowiedzialnych

3 Szczegółowe informacje na ten temat można znaleźć na stronie internetowej Volkswagena Poznań, pod adresem internetowym: https://volkswagen-poznan.pl/pl/fabryki. Informacje są dostępne również na stronie internetowej starostwa powiatowego we Wrześni: https://www.wrzesnia.powiat.pl/474,powiat. 
Tabela 2. Działania Volkswagena w Białężycach na rzecz powiatu wrzesińskiego

\begin{tabular}{|c|c|}
\hline Grupa działań & Wyszczególnienie \\
\hline $\begin{array}{l}\text { Działania na } \\
\text { rzecz społecz- } \\
\text { ności lokalnej }\end{array}$ & $\begin{array}{l}\text { Wsparcie placówek edukacyjnych i badawczych, m.in. utworzenie Centrum Badań } \\
\text { i Rozwoju Nowoczesnych Technologii w Grzymysławicach, dofinansowanie Cen- } \\
\text { trum Edukacji Zawodowej we Wrześni. } \\
\text { Projekty rewitalizacyjne w wioskach wokół fabryki we Wrześni, np. rewitalizacja } \\
\text { otoczenia wokół świetlic, budowa boiska sportowego do piłki nożnej w Chociczy } \\
\text { Wielkiej. } \\
\text { Coroczna organizacja festynów i lokalnych uroczystości oraz imprez kulturalnych } \\
\text { i sportowych, takich jak: dożynki, mecze piłki nożnej, Akcja Zebra. } \\
\text { Sponsoring warsztatów terapii zajęciowej. } \\
\text { Systematyczny dialog z mieszkańcami o problemach wynikających z funkcjonowa- } \\
\text { nia zakładu i oczekiwaniach społeczności (spotkania organizowane są dwa razy } \\
\text { w roku). } \\
\text { Wybudowanie nowej siedziby Państwowej Straży Pożarnej w Białężycach. }\end{array}$ \\
\hline $\begin{array}{l}\text { Działania na } \\
\text { rzecz środo- } \\
\text { wiska przy- } \\
\text { rodniczego }\end{array}$ & $\begin{array}{l}\text { Wdrożenie norm proekologicznych ISO } 14.001 \text { i ISO } 50.001 \text {. } \\
\text { Program nasadzeń drzew w sąsiedztwie zakładu (25 tys. w } 2018 \text { r. oraz } 18 \text { tys. do } \\
\text { końca maja } 2019 \text { r.). } \\
\text { Odzysk ciepła z procesów odlewniczych - do ogrzewania okolicznych budynków } \\
\text { i szpitala. } \\
\text { Program podnoszenia świadomości ekologicznej wśród pracowników i dostawców } \\
\text { poprzez projekty takie, jak „Maj - miesiąc ochrony środowiska”, sprzątanie lasu, } \\
\text { akcje obniżenia ilości odpadów plastikowych. } \\
\text { Program Think Blue Factory - redukcja o } 50 \% \text { do } 2025 \text { r. zużycia energii, emisji } \\
\text { CO }_{2} \text {, emisji lotnych związków organicznych, zużycia wody i odpadów (w stosunku } \\
\text { do roku 2010), w tym: } \\
\text { - finansowanie inwestycji podnoszących efektywność energetyczną (programy } \\
\text { „Fabryka niezależna energetycznie”, „Elektromobilność”) i oszczędność wody; } \\
\text { wskaźniki w tym zakresie są monitorowane miesięcznie i przeliczane na jednost- } \\
\text { kę wytworzonego produktu; } \\
\text { - „niebieskie granty” - konkursy organizowane we współpracy z Fundacją Nasza } \\
\text { Ziemia, których celem jest przygotowanie i realizacja działań na rzecz ochrony } \\
\text { przyrody oraz edukacji ekologicznej uświadamiającej konieczność racjonalnego } \\
\text { korzystania z zasobów; } \\
\text { - współpraca z Uniwersytetem Przyrodniczym w Poznaniu w zakresie opracowania } \\
\text { planu działań VWP na rzecz redukcji emisji pyłów i CO }{ }_{2} \text {. } \\
\text { Współpraca z GOAP - Związkiem Międzygminnym „Gospodarka Odpadami Aglo- } \\
\text { meracji Poznańskiej”- w zakresie akcji prośrodowiskowej dotyczącej redukcji odpa- } \\
\text { dów plastikowych. }\end{array}$ \\
\hline
\end{tabular}

Źródło: opracowanie własne na podstawie materiałów uzyskanych w przedsiębiorstwie.

\section{i zaangażowanych społecznie firm przyznawane przez tygodnik „Polityka”, firmę doradczą Deloitte oraz Forum Odpowiedzialnego Biznesu ${ }^{4}$.}

4 Analizując kwestię społecznej odpowiedzialności koncernu, warto jednak wspomnieć o strategicznych decyzjach kierownictwa, które mogą wpływać na społeczeństwo oraz rzutować na całościowy wizerunek firmy (a na które przedstawiciele oddziałów, w tym zakładów Volkswagena w Wielkopolsce, zupełnie nie mają wpływu). Decyzją Dyrektora Urzędu Ochrony Konkurencji i Konsumenta (nr DOZIK-2/2020 z 15 stycznia 2020 r., w momencie złożenia publikacji do druku nieprawomocna), na przedsiębiorstwo Volkswagen Group Polska nałożona została kara w wysokości 120 mln zł za naruszenie praw konsumenckich przy instalowaniu w latach 2008-2016 w samochodach oprogramowania do manipulowania emisją spalin. Nieuczciwe praktyki rynkowe wynikały $\mathrm{z}$ wprowadzania klientów $\mathrm{w}$ błąd $\mathrm{w}$ materiałach promocyjnych oraz dokumentach homologacyjnych: rzeczywisty poziom emisji spalin był wyższy niż deklarowany. 
Władze samorządowe dostrzegają wiele z powyższych pozytywnych skutków inwestycji. Obok nich wymieniają również liczne korzyści ekonomiczne, jakie były lub będą możliwe wskutek inwestycji Volkswagena - są to:

- Rozwój rynku pracy i wyeliminowanie bezrobocia na obszarze powiatu wrzesińskiego - utworzone miejsca pracy wystarczają dla wszystkich chcących i mogących pracować (w istocie pracownicy VW dojeżdżają do zakładu z obszaru całej Wielkopolski).

- Powstanie nowych przedsiębiorstw we Wrzesińskiej Strefie Aktywności Gospodarczej, produkujących komponenty na rzecz Volkswagena w Białężycach: Benteler Automotive Poland Sp. z o.o. (konstrukcje samochodowe, silniki i układy wydechowe, elementy podwozi i komponentów), Sitech Sp. z o.o. (metalowe stelaże do siedzisk samochodowych), Inalfa Roof Systems (systemy dachowe do samochodów osobowych klasy premium).

- Rozwój rynku nieruchomości mieszkalnictwa wielorodzinnego - nowe inwestycje deweloperskie na obszarze miasta Wrześni.

- Rozwój sektora usługowego zaspokajającego potrzeby ludności - napędzony dochodami uzyskiwanymi w związku z nowymi przyjęciami do pracy.

- Oczekiwane wpływy podatkowe z podatków od nieruchomości (po okresie zwolnienia z tego podatku na obszarze WSAG) oraz - już zauważalne - rosnące wpływy z podatków dochodowych CIT i PIT.

Wypowiedzi wskazują zatem na występowanie pozytywnych efektów mnożnikowych opisywanej inwestycji: zarówno popytowych (takich jak nowe przedsiębiorstwa współpracujące z zakładem Volkswagena), jak i dochodowych - powstałych wskutek zwiększonych zarobków pracowników korporacji. Władze samorządowe dostrzegają jednak również pewne niekorzyści powstałe w wyniku rozpoczęcia funkcjonowania tak dużego zakładu. Problemem staje się większe natężenie ruchu, szczególnie w godzinach szczytu. Aby rozwiązać zaistniałą sytuację, od lutego 2019 r. budowana jest wschodnia obwodnica Wrześni, łącząca drogi krajowe numer 15 i 92. Pracownicy lokalnych urzędów zauważają również ucieczkę pracowników z zakładów istniejących wcześniej we Wrześni do Volkswagena oraz napływ ludzi, z których część nie melduje się na obszarze powiatu wrzesińskiego.

\section{Ocena wpływu inwestycji na powiat wrzesiński przez mieszkańców}

Spośród 415 mieszkańców powiatu wrzesińskiego, którzy wzięli udział w badaniu metodą wywiadów bezpośrednich, zdecydowana większość - 410 osób $(98,8 \%)$ zadeklarowała, że słyszała o zakładzie Volkswagena w Białężycach koło Wrześni. Osoby te odpowiadały na dalsze pytania.

Wśród 410 respondentów 10\% stanowiły osoby, które były pracownikami zakładu lub miały w gospodarstwie domowym osobę pracującą w zakładzie; 43\% deklarowało, że ktoś ze znajomych lub dalszej rodziny pracuje w zakładzie, a 47\% nie miało związku z zakładem. 
Osoby uczestniczące w badaniu chętnie odpowiadały na pytanie dotyczące inwestycji Volkswagena. Wyniki przedstawione są z podziałem na ocenę ilościową wpływu na rozwój powiatu wrzesińskiego (ryc. 1) oraz jakościową - będącą uzasadnieniem dla pozytywnej lub negatywnej opinii na temat oddziaływania zakładu na otoczenie (tab. 3).

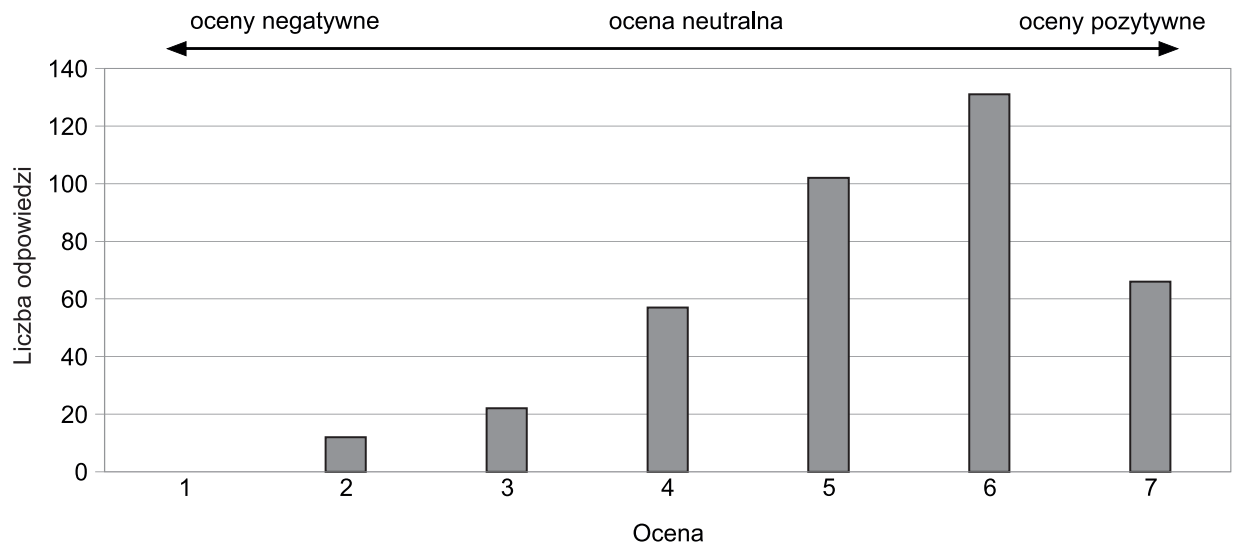

Ryc. 1. Ocena wpływu inwestycji Volkswagena na rozwój powiatu wrzesińskiego - wyniki badania wśród mieszkańców

Źródło: badanie ankietowe wśród mieszkańców $(\mathrm{n}=410)$.

Tabela 3. Wyjaśnienia pozytywnych lub negatywnych ocen inwestycji Volkswagena na terenie powiatu wrzesińskiego

\begin{tabular}{clc}
\hline Lp. & \multicolumn{1}{c}{ Pozytywne aspekty inwestycji } & Liczba wskazań \\
\hline 1 & Nowe miejsca pracy/spadek bezrobocia & 211 \\
2 & Rozwój miasta i powiatu, inwestycje komunalne oraz finansowane przez VW & 47 \\
3 & Rozwój infrastruktury drogowej & 43 \\
4 & Rozpoznawalność, prestiż Wrześni & 19 \\
5 & Rozwój sektora usługowego/wzrost liczby klientów usług & 14 \\
6 & Nowi mieszkańcy, rozwój mieszkalnictwa & 14 \\
7 & Otwarcie nowych firm & 13 \\
8 & Wpływy podatkowe & 12 \\
9 & Dalsze szanse rozwojowe & 9 \\
10 & Wzrost zarobków mieszkańców & 5 \\
11 & Nowe połączenia PKP & Negatywne aspekty inwestycji \\
\hline Lp. & & 1 \\
\hline 1 & Wzmożony ruch/korki na ulicach & 65 \\
2 & Wzrost cen & 8 \\
3 & Za dużo ludności napływowej & 8 \\
4 & Hałas & 7 \\
5 & Ucieczka pracowników z istniejących firm & 3 \\
6 & Brak miejsc parkingowych & 3 \\
\hline
\end{tabular}

Źródło: badanie ankietowe wśród mieszkańców $(\mathrm{n}=410)$ 
Średnia ocena wpływu Volkswagena na rozwój powiatu wrzesińskiego uzyskana w badaniu jest wysoka i wynosi 5,32. Aż 66 rozmówców (16\%) wskazało na bardzo pozytywny wpływ inwestycji na rozwój lokalny (ocena 7), a $131(32 \%)$ pozytywny (ocena 6 ). Jednocześnie nikt nie wskazał na bardzo negatywny wpływ (ocena 1 ), a na negatywny (ocena 2 ) tylko 12 osób (3\%).

Taki rozkład statystyczny odpowiedzi (prawostronnie asymetryczny) wskazuje na dobry odbiór inwestycji i pozytywną ocenę jej znaczenia w rozwoju powiatu wrzesińskiego. Wyniki wskazują też na fakt, że Volkswagen jest postrzegany jako dobry i wiarygodny pracodawca.

Wśród wymienionych przez mieszkańców powiatu wrzesińskiego pozytywnych aspektów wpływu inwestycji Volkswagena na rozwój lokalny (tab. 3) na szczególną uwagę zasługują nowe miejsca pracy lub spadek bezrobocia - ten walor został wskazany przez 211, a więc ponad połowę respondentów. Wpływ na rynek pracy w oczach mieszkańców jest więc najważniejszym pozytywnym efektem opisywanej inwestycji.

Na drugim miejscu wśród pozytywnych aspektów lokalizacji oddziału niemieckiego koncernu jest kategoria „rozwój miasta i powiatu”. Rozmówcy taką odpowiedź formułowali literalnie, niekiedy zaś wskazywali na zmiany, inwestycje lub nowe sposoby zagospodarowania, jakie zaszły na terenie powiatu wrzesińskiego. Szczególnym typem inwestycji, który często wymieniany był przez respondentów, był „rozwój infrastruktury drogowej”. Niektórzy rozmówcy uściślali, że chodzi m.in. o drogi w okolicy zakładu oraz rozpoczęcie budowy obwodnicy miasta. Należy mieć na uwadze, że elementy te zostały zrealizowane dzięki środkom zaangażowanym przez lokalne samorządy $\mathrm{w}$ związku $\mathrm{z}$ analizowaną inwestycją lub niezależnie od niej, a także dzięki środkom i działaniom Volkswagena.

Część respondentów dostrzega również dochodowe efekty mnożnikowe, będące efektem uruchomienia zakładu Volkswagena. Wśród odpowiedzi potwierdzających wzrost siły nabywczej ludności padały m.in. takie stwierdzenia: „mieszkańcy kupują więcej”, „miejscowe butiki odczuwają, że mieszkańcy mają więcej pieniędzy”, „społeczeństwo jest bogatsze”, ,jest więcej usług”, „w restauracji jest więcej klientów: miejscowych i przyjezdnych". Odpowiedzi tych udzielali często właściciele małych sklepów lub punktów gastronomicznych. Część rozmówców podkreśla również szanse dla innych firm powiązanych z zakładem Volkswagena, świadczące o zaopatrzeniowym efekcie mnożnikowym. Wśród odpowiedzi dotyczących pozytywnych efektów inwestycji Volkswagena dla powiatu wrzesińskiego warto przywołać takie, jak: „Wrześnią zainteresowało się dużo inwestorów”, „Przy okazji powstania zakładu powstały też inne” czy że efektem inwestycji jest: „Rozwój gospodarczy - wzrost liczby firm produkujących części dla Volkswagena".

Co ciekawe, dodatkowo dostrzeganym przez mieszkańców pozytywnym rezultatem lokalizacji Volkswagena we Wrześni są elementy wizerunkowe wyrażające się w sformułowaniach typu: „rozpoznawalność Wrześni”, „prestiż miasta”, „miasto wydaje się ciekawsze i bardziej znane”.

Część respondentów dostrzega jednak również negatywne strony inwestycji, a wśród nich szczególnie widoczny i, jak się wydaje, uciążliwy dla mieszkańców 
jest wzmożony ruch samochodowy oraz korki na ulicach. Element ten został wskazany przez 65 respondentów, z których część doprecyzowywała, że chodzi głównie o godziny szczytu i ruch spowodowany przez dojazd do pracy w zakładzie Volkswagena lub powrót z pracy w zakładzie.

Inne negatywne aspekty inwestycji wymieniły pojedyncze osoby. Wśród nich był m.in. wzrost cen, w tym szczególnie nieruchomości. Jeden z mieszkańców wskazał, że „sporo wykształconych osób przyjechało do miasta, ale podniosły się ceny". Inni rozmówcy trochę narzekali, że Września stała się celem migracji wielu ludzi, co w konsekwencji spowodowało, że nieco zaburzony został spokojny charakter miasta. Ten aspekt występuje w takich wypowiedziach, jak: „pojawia się coraz więcej ludzi, w tym obcokrajowców”, „miasto zakorkowane, nie ma gdzie zaparkować”, „hałas od tirów, ciężko dojechać do Wrześni”. Istotnym negatywnym efektem dla części lokalnych przedsiębiorców może być również to, że utracili oni pracowników, którzy przenieśli się do Volkswagena. Nowych na ich miejsce niełatwo znaleźć, zwłaszcza że konkurowanie z tak dużym zakładem pod względem wynagrodzenia i warunków pracy może być trudne.

Rozmówcy, którzy oceniali wpływ Volkswagena na rozwój lokalny jako neutralny (4), wskazywali zarówno korzyści, jak i negatywne strony wynikające $z$ budowy i funkcjonowania zakładu. Często podkreślano, że są miejsca pracy, ale są też korki na drogach. Niektórzy stwierdzali, że rozbudowana została infrastruktura w mieście i na obrzeżach, ale jednocześnie wzrósł ruch samochodowy i brakuje miejsc parkingowych w mieście.

Należy jednak podkreślić, że liczba wskazań i różnorodność dla pozytywnych efektów realizacji inwestycji w oczach mieszkańców jest znacznie większa niż efektów negatywnych.

\section{Podsumowanie i dyskusja}

W świetle przeprowadzonego badania można stwierdzić, że na lokalizację zakładu Volkswagena w powiecie wrzesińskim w województwie wielkopolskim złożyło się wiele czynników. Do najważniejszych zaliczyć należy bliskość istniejących już w Poznaniu zakładów Volkswagena (z którymi nowy zakład będzie blisko współpracował) oraz położenie w zachodniej Polsce, w województwie wielkopolskim - regionie o dobrym wizerunku, z potencjałem siły roboczej (zarówno wykwalifikowanych specjalistów, jak i pracowników produkcyjnych). Istotny był też duży niezagospodarowany teren, dobrze przygotowany od strony administracyjnej pod inwestycję i wypromowany oraz warunki finansowe prowadzenia działalności w tym miejscu. Badanie pozwoliło zatem wykazać, że - obok kosztowych czynników lokalizacji (związanych z terenem inwestycji, kosztami pracy, ulgami podatkowymi) - znaczenie miały także czynniki zaopatrzeniowe (m.in. oczekiwana wydajność pracy) oraz miękkie (m.in. dobry wizerunek regionu, współpraca z władzami lokalnymi).

Najważniejszym efektem realizacji inwestycji jest wpływ na lokalny i regionalny rynek pracy - w zakładzie pracuje prawie 3000 osób. Informacje uzyskane 
od przedstawicieli inwestora - Volkswagena Poznań - wskazują, że przedsiębiorstwo - poza swoją podstawową działalnością - podejmuje inicjatywy i działania korzystne dla otoczenia społecznego i przyrodniczego, a więc wpisujące się w założenia koncepcji społecznej odpowiedzialności biznesu. Są to: sponsoring, akcje promocyjne i wydarzenia, z których korzystają mieszkańcy powiatu wrzesińskiego. Wywiady pogłębione $z$ władzami samorządowymi potwierdziły występowanie efektów mnożnikowych inwestycji: zarówno popytowych (wzrost zapotrzebowania na przedsiębiorstwa współpracujące $z$ nowo powstałym zakładem, dostarczające komponenty), jak i dochodowych (w postaci wzrostu dochodów mieszkańców, które są wydawane na obszarze Wrześni i w konsekwencji przekładają się na wzrost obrotów punktów usługowych).

Wywiady kwestionariuszowe wśród mieszkańców pozwoliły ponadto wykazać, że odbiór inwestycji jest pozytywny, a obok utworzenia nowych miejsc pracy szczególnie pozytywnie oceniane są rozwój infrastruktury drogowej oraz inne towarzyszące inwestycje komunalne. Część respondentów podaje jednak, że w konsekwencji utworzenia tak dużego zakładu pojawiły się w mieście korki, szczególnie $w$ godzinach zmian $w$ fabryce, i że jest to związane $z$ dojazdami osób, które nie mieszkają we Wrześni (a niekiedy w powiecie wrzesińskim), lecz jedynie przejeżdżają przez miasto $\mathrm{w}$ drodze do i z pracy. Efektom ekonomicznym i społecznym stanowiącym skutek inwestycji towarzyszą duże zmiany w zagospodarowaniu przestrzennym (inwestycja ma 220 ha, wybudowano nowe drogi) oraz wpływ na środowisko przyrodnicze chociażby w postaci hałasu lub emisji spalin z zakładu i dojeżdżających tam samochodów. Inwestycja stworzyła zatem dla gminy nowe możliwości rozwoju, ale również nowe wyzwania, którym władze będą musiały sprostać (np. w celu rozwiązania narastających problemów komunikacyjnych rozpoczęto budowę obwodnicy Wrześni). Podobny wpływ lokalizacji dużych inwestycji na rozwój regionalny i lokalny (z jednej strony pozytywny, z drugiej stwarzający nowe wyzwania) wykazany został również w innych badaniach w Polsce, np. Dziemianowicza (1997), Stryjakiewicza (2004) i Tobolskiej (2010).

Należy mieć na uwadze kilka ograniczeń w interpretacji wyników badań. Analiza zaopatrzeniowych efektów mnożnikowych, m.in. w zakresie rozmiarów współpracy zakładu Volkswagena z przedsiębiorstwami będącymi dostarczycielami surowców, półproduktów czy podmiotami oferującymi usługi w ramach outsourcingu, wymagałaby uzyskania od Volkswagena dalszych, szczegółowych danych. Ponadto inwestycja Volkswagena we Wrześni została ukończona w 2016 r., toteż czas, jaki upłynął od jej wdrożenia, jest stosunkowo krótki. Niektóre z rezultatów funkcjonowania zakładu dla powiatu wrzesińskiego - zarówno pozytywnych, jak i negatywnych - mogą się ujawnić po kilku, a nawet kilkunastu latach. Warto będzie więc powtórzyć analizę wpływu zakładu Volkswagena na otoczenie po pewnym czasie. 


\section{Literatura}

Adamczyk J. 2009. Społeczna odpowiedzialność przedsiębiorstw. PWE, Warszawa.

Atrakcyjność inwestycyjna województw i podregionów w Polsce. 2014. Raport Instytutu Badań nad Gospodarką Rynkową, przygotowany przez zespół pod red. M. Nowickiego. Gdańsk.

Atrakcyjność inwestycyjna regionów 2017. Raport na zlecenie Polskiej Agencji Inwestycji i Handlu S.A. przygotowany przez zespół pod kierunkiem H. Godlewskiej-Majkowskiej w Szkole Głównej Handlowej. Warszawa.

Bernatt M. 2009. Społeczna odpowiedzialność biznesu. Wymiar konstytucyjny i międzynarodowy. Wydawnictwo Naukowe Wydziału Zarządzania Uniwersytetu Warszawskiego, Warszawa.

Budner W. 2004. Lokalizacja przedsiębiorstw: aspekty ekonomiczno-przestrzenne i środowiskowe. Wydawnictwo Akademii Ekonomicznej w Poznaniu, Poznań, s. 26-41.

Caroll A.B., Shabana K.M. 2010. The business case for corporate social responsibility: A review of concepts, research and practice. International Journal of Management Reviews, 12 (1): 85-105.

Cieślik A. 2007. Czynniki lokalizacji spółek z udziałem handlu zagranicznego w Polsce. Gospodarka Narodowa, 3: 25-48.

Domański B. 2001. Kapitał zagraniczny w przemyśle Polski. Prawidłowości rozmieszczenia, uwarunkowania i skutki. Instytut Geografii i Gospodarki Przestrzennej Uniwersytetu Jagiellońskiego, Kraków.

Domański B. 2004. Local and regional embeddedness of foreign industrial investors in Poland. [W:] M. Paszkowski (red.), Effectiveness, geographical space, quality of life. Prace Geograficzne, 114: $37-54$.

Domański B., Gwosdz K. 2010. Multiplier effects in local and regional development. Quaestiones Geographicae, 29(2): 27-38.

Domański B., Gwosdz K., Huculak M., Wiedermann K. 2005. Oddziaływanie SSE Euro-Park Mielec na otoczenie lokalne. Powiązania firm i efekty mnożnikowe. [W:] Dziesięć lat doświadczeń pierwszej polskiej specjalnej strefy ekonomicznej Mielec 1995-2005. Instytut Goegrafii i Gospodarki Przestrzennej UJ, Kraków, ARP o. Mielec.

Dyba W. 2013. Wpływ dużych przedsiębiorstw na rozwój regionalny na przykładzie województwa wielkopolskiego. Rozwój Regionalny i Polityka Regionalna, 21: 21-39.

Dziemianowicz W. 1997. Kapitał zagraniczny a rozwój lokalny i regionalny w Polsce (Vol. 20). Uniwersytet Warszawski, Europejski Instytut Rozwoju Regionalnego i Lokalnego, Warszawa.

Dziemianowicz W., Łukomska J., Ambroziak A.A. 2019. Location factors in foreign direct investment at the local level: the case of Poland. Regional Studies, 53(8): 1183-1192.

Fijałkowski P. 2016. Fabryka Volkswagena pod Wrześnią otwarta. Gazeta Wyborcza, 24.10.2016.

Godlewska H. 2001. Lokalizacja działalności gospodarczej. Wybrane zagadnienia. Wyd. WSHiFM, Warszawa, s. 13-17, 50-72.

Godlewska-Majkowska H. 2013. Atrakcyjność inwestycyjna regionów Polski na tle Unii Europejskiej. SGH (WSE), Warszawa.

Godlewska-Majkowska H. 2015. Lokalizacja produkcji przemysłowej. [W:] K. Kuciński (red.), Geografia ekonomiczna. Oficyna Wolters Kluwer Business, Kraków.

Jarczewski W. 2012. Pozyskiwanie inwestorów do gmin. Wolters Kluwer Polska, Warszawa.

Kaczyńska M. 2014 Wrzesińska strefa aktywności gospodarczej wciąż z terenami. Głos Wielkopolski, 21.10.2014.

Kilar W. 2018. Corporations as an Object of Research in Geography of Industry. Studies of the Industrial Geography Commission of the Polish Geographical Society, 32(4): 69-85.

Kortus B. 1983. Geografia przemysłu: wybrane aktualne kierunki i problemy badawcze. IGiPZ PAN, Warszawa.

Kudłak R. 2018. Instytucjonalne uwarunkowania społecznej odpowiedzialności biznesu. Wydawnictwo Naukowe UAM, Poznań.

Płaziak M., Szymańska A.I. 2014. Klasyczne czynniki w procesie lokalizacji przedsiębiorstwa na wybranych przykładach. Przedsiębiorczość-Edukacja, 10: 71-84.

Rachwał T. 2018. Research Issues of Structural Changes in Polish Industry in Geography of Industry. Studies of the Industrial Geography Commission of the Polish Geographical Society, 32(4): 86-109. 
Rachwał T., Wiedermann K. 2008. Multiplier effects in regional development: the case of the motor vehicle industry in Silesian voivodeship (Poland). Quaestiones Geographicae, 27B/1: 68-80.

Stachowiak K. 2007. Instytucjonalne uwarunkowania bezpośrednich inwestycji zagranicznych w Polsce. Bogucki Wydawnictwo Naukowe, Poznań.

Stachowiak K. 2011. Rola koncepcji zakorzenienia w geograficznych badaniach nad globalizacją. Podstawowe Idee I Koncepcje w Geografii, 5: 83-99.

Stryjakiewicz T. 1999. Adaptacja przestrzenna przemysłu w Polsce w warunkach transformacji. Wydawnictwo Naukowe UAM, Poznań.

Stryjakiewicz T. 2004. Wpływ inwestorów zagranicznych na rozwój regionalny i lokalny na przykładzie GlaxoSmothKline Pharmaceuticals S.A. w Poznaniu. Bogucki Wydawnictwo Naukowe, Poznań.

Stryjakiewicz T. 2007. Transformacja gospodarki w ujęciu strukturalnym i przestrzennym. Nowe czynniki działalności gospodarczej. [W:] H. Rogacki (red.), Geografia społeczno-gospodarcza Polski. Wyd. Nauk. PWN, Warszawa, s. 177-180.

Stryjakiewicz T. 2009. Nowe spojrzenie na czynniki lokalizacji działalności gospodarczej. [W:] I. Jażewicz (red.), Współczesne problemy przemian strukturalnych przestrzeni geograficznej. Wydawnictwo Naukowe Akademii Pomorskiej, Słupsk, s. 94-102.

Śleszyński P. 2018. Research Topics of Geography of Enterprise and Decision-Control Functionsin Poland against Global Trends. Studies of the Industrial Geography Commission of the Polish Geographical Society, 32(4): 22-47.

Tarski 1963. Transport jako czynnik lokalizacji produkcji. Państwowe Wydawnictwo Ekonomiczne. Warszawa.

Tobolska A. 2010. Miejsce inwestora zagranicznego w przestrzeni lokalnej i regionalnej na przykładzie Sweedwood w Chlastawie. Bogucki Wydawnictwo Naukowe, Poznań.

Tobolska A. 2011. Czynniki lokalizacji fabryk wybranych korporacji międzynarodowych w Polsce. Rozwój Regionalny i Polityka Regionalna, Biuletyn Instytutu Geografii Społeczno-Ekonomicznej i Gospodarki Przestrzennej UAM, 15.

Tobolska A. 2017. Strategie przedsiębiorstw międzynarodowych oraz ich oddziaływania w przestrzeni lokalnej i regionalnej. Wydawnictwo Naukowe UAM, Poznań.

Tobolska A. 2018. Strategies of International Companies as a Research Problem of Geography of Enterprise. Studies of the Industrial Geography Commission of the Polish Geographical Society, 32(4): 48-68.

Wdowicka M. 2005. Bezpośrednie inwestycje zagraniczne i inwestycje samorządowe w aglomeracji poznańskiej w okresie transformacji ustrojowej. Bogucki Wydawnictwo Naukowe, Poznań.

Wiedermann K. 2008. Koncepcja efektów mnożnikowych w wyznaczaniu wpływu przedsiębiorstw na otoczenie społeczno-gospodarcze. Prace Komisji Geografii Przemysłu Polskiego Towarzystwa Geograficznego, 11: 98-106.

Wieloński A. 2005. Geografia przemysłu. Wydawnictwo Uniwersytetu Warszawskiego, Warszawa.

Weber A. 1909. Über den Standort der Industrien. Tübingen.

Wojtyra B. 2019. Wrzesińska Strefa Aktywności Gospodarczej. [W:] B. Wojtyra (red.), Lokalne strefy aktywności gospodarczej w procesie rozwoju obszarów wiejskich województwa wielkopolskiego. Bogucki Wydawnictwo Naukowe, Poznań, s. 159-166.

Zielona Księga w sprawie koncepcji społecznej odpowiedzialności 2001. Komisja Europejska, Bruksela.

Zioło Z. 2009. Procesy kształtowania się światowych korporacji i ich wpływ na otoczenie. Prace Komisji Geografii Przemysłu Polskiego Towarzystwa Geograficznego, 12: 11-32.

\section{Location factors and effects of the Volkswagen production plant in Września poviat}

\footnotetext{
Abstract: The article presents an analysis of the location factors and location effects of the Volkswagen-Crafter production plant in Białężyce near Września (Western Poland). The presented results are based on individual deep interviews with representatives of the enterprise and local government authorities as well as questionnaire interviews with local residents. The study showed that apart from
} 
the cost factors (related to the investment area and tax exemptions), also the supply factors (e.g. expected labour productivity) and soft factors (e.g. good image of the region, cooperation with local authorities) were important when making the location decision. The biggest benefit for the Września poviat that result from the investment is the creation of new jobs. However, the plant's authorities undertake many activities that are beneficial for the local community, such as sponsoring of local events and financing pro-environmental campaigns. Investments effects are also connected with the increase in turnover of the local service providers, the influx of new residents and location of new companies cooperating with Volkswagen.

Key words: corporate social responsibility, location factors, multiplier effects, Volkswagen, Września poviat 